\title{
Sea Level-Driven Marsh Migration Results in Rapid Net Loss of Carbon
}

Alexander J. Smith

Virginia Institute of Marine Science

Matthew L. Kirwan

Virginia Institute of Marine Science

Follow this and additional works at: https://scholarworks.wm.edu/vimsarticles

Part of the Soil Science Commons

\section{Recommended Citation}

Smith, Alexander J. and Kirwan, Matthew L., Sea Level-Driven Marsh Migration Results in Rapid Net Loss of Carbon (2021). Geophysical Research Letters, 48(e2021GL092420).

DOI: 10.1029/2021GL092420

This Article is brought to you for free and open access by the Virginia Institute of Marine Science at W\&M ScholarWorks. It has been accepted for inclusion in VIMS Articles by an authorized administrator of W\&M ScholarWorks. For more information, please contact scholarworks@wm.edu. 


\section{Geophysical Research Letters}

\author{
RESEARCH LETTER \\ 10.1029/2021GL092420 \\ Key Points: \\ - Sea level-driven marsh migration \\ leads to a 50\% reduction in carbon \\ stocks, driven primarily by the loss \\ of carbon stored in woody biomass \\ - We propose a replacement-time \\ metric that indicates marsh soils \\ must survive centuries before they \\ can offset forest carbon loss \\ - Large timescales of carbon \\ replacement indicate that marsh \\ migration results in a net loss of \\ carbon that is overlooked in coastal \\ budgets
}

Supporting Information:

Supporting Information may be found in the online version of this article.

Correspondence to:

A. J. Smith,

ajsmith@vims.edu

Citation:

Smith, A. J., \& Kirwan, M. L. (2021). Sea level-driven marsh migration results in rapid net loss of carbon. Geophysical Research Letters, 48, e2021GL092420. https://doi.org/10.1029/2021GL092420

Received 26 JAN 2021

Accepted 4 JUN 2021

Author Contributions:

Conceptualization: Alexander J.

Smith, Matthew L. Kirwan

Data curation: Alexander J. Smith

Formal analysis: Alexander J. Smith

Funding acquisition: Matthew L.

Kirwan

Investigation: Alexander J. Smith Methodology: Alexander J. Smith, Matthew L. Kirwan

Project Administration: Alexander J.

Smith, Matthew L. Kirwan

Resources: Matthew L. Kirwan

Supervision: Matthew L. Kirwan

Validation: Alexander J. Smith,

Matthew L. Kirwan

Visualization: Alexander J. Smith

Writing - original draft: Alexander

J. Smith

Writing - review \& editing:

Alexander J. Smith, Matthew L. Kirwan

(C) 2021. American Geophysical Union. All Rights Reserved.

\section{Sea Level-Driven Marsh Migration Results in Rapid Net Loss of Carbon}

\author{
Alexander J. Smith ${ }^{1}$ (D) and Matthew L. Kirwan' ${ }^{1}$ (D) \\ ${ }^{1}$ Virginia Institute of Marine Science, College of William and Mary, Gloucester Point, VA, USA
}

\begin{abstract}
Sea level rise alters coastal carbon cycling by driving the rapid migration of coastal ecosystems, salinization of freshwater systems, and replacement of terrestrial forests with tidal wetlands. Wetland soils accumulate carbon (C) at faster rates than terrestrial soils, implying that sea level rise may lead to enhanced carbon accumulation. Here, we show that carbon stored in tree biomass greatly exceeds carbon stored in adjacent marsh soils so that marsh migration reduces total carbon stocks by $\sim 50 \%$ in less than 100 years. Continued marsh soil carbon accumulation may eventually offset forest carbon loss, but we estimate that the time for replacement is similar to estimates of marsh survival (i.e., centuries), which suggests that forest $\mathrm{C}$ may never be replaced. These findings reveal a critical $\mathrm{C}$ source not included in coastal $\mathrm{C}$ budgets driven by migrating ecosystems and rapidly shifting allocations between carbon stored in soils and biomass.
\end{abstract}

Plain Language Summary Forests along the upland edge of salt marshes are being killed by rising sea levels and replaced with salt marsh in a process called marsh migration. Marsh soils, unlike soils in forest, quickly accumulate carbon in their soils. This indicates that marsh migration could possibly increase carbon storage across the landscape. Here, we show the opposite, that sea level rise reduces coastal carbon stocks through the loss of woody aboveground biomass. This loss is partially offset with expanding organic soil in the newly formed marsh, but the amount of carbon lost from forest mortality is far greater than that gained by the growing marsh soils. Continued carbon accumulation in wetland soils may eventually compensate for forest carbon loss, but the time it would take for marshes to replace that lost carbon is at the scale of centuries, which is approximately the same amount of time predicted for marshes to drown from rising sea levels. This suggests that forest carbon may never be replaced and reveals a critical source of carbon under climate driven landscape changes.

\section{Introduction}

Coastal wetlands are thought to disproportionally influence the global carbon (C) budget because of $\mathrm{C}$ accumulation rates 1 to 2 orders of magnitude greater than terrestrial systems (Chmura et al., 2003; Mcleod et al., 2011). Salt marshes, mangroves, and seagrasses account for $\sim 50 \%$ of $\mathrm{C}$ buried in the ocean despite covering $<2 \%$ of the ocean's surface (Duarte et al., 2005). However, sea level rise, reduced sediment supply, and other anthropogenic stressors threaten the persistence and strength of the coastal carbon sink (Kirwan \& Megonigal, 2013; Saintilan et al., 2020). Extensive historical loss of coastal ecosystems (Kirwan \& Gedan, 2019) suggests that coastal wetlands are simultaneously valuable yet vulnerable C sinks (Hopkinson et al., 2012; Nahlik \& Fennessy, 2016; Theuerkauf \& Rodriguez, 2017), making it imperative to understand how the coastal $\mathrm{C}$ sink will respond to global change (Ward et al., 2020).

For more than a decade, blue carbon research has focused on quantifying $\mathrm{C}$ stored in the soils of single ecosystems, often at single points within an ecosystem (Chmura et al., 2003; Duarte et al., 2005; Mcleod et al., 2011; Ward et al., 2020). However, climate change limits the applicability of this traditional blue carbon approach by altering the position of ecotones, the spatial extents of ecosystems within the coastal landscape, and the partitioning of $\mathrm{C}$ between soils and vegetation (Kirwan \& Megonigal, 2013; Kirwan, Temmerman, et al., 2016; K. Krauss et al., 2018; Osland et al., 2017; J. A. Smith, 2013). For example, sea level rise is leading to the widespread migration of wetlands into retreating upland forests across the Atlantic coast of North America (Kirwan \& Gedan, 2019; Schieder et al., 2018), where coastal ecosystems and their carbon pools are expected to change rapidly (i.e., at decadal time scales) (Enwright et al., 2016; K. Krauss et al., 2018; Schieder \& Kirwan, 2019; Wang et al., 2019). Following conventional blue carbon approaches 


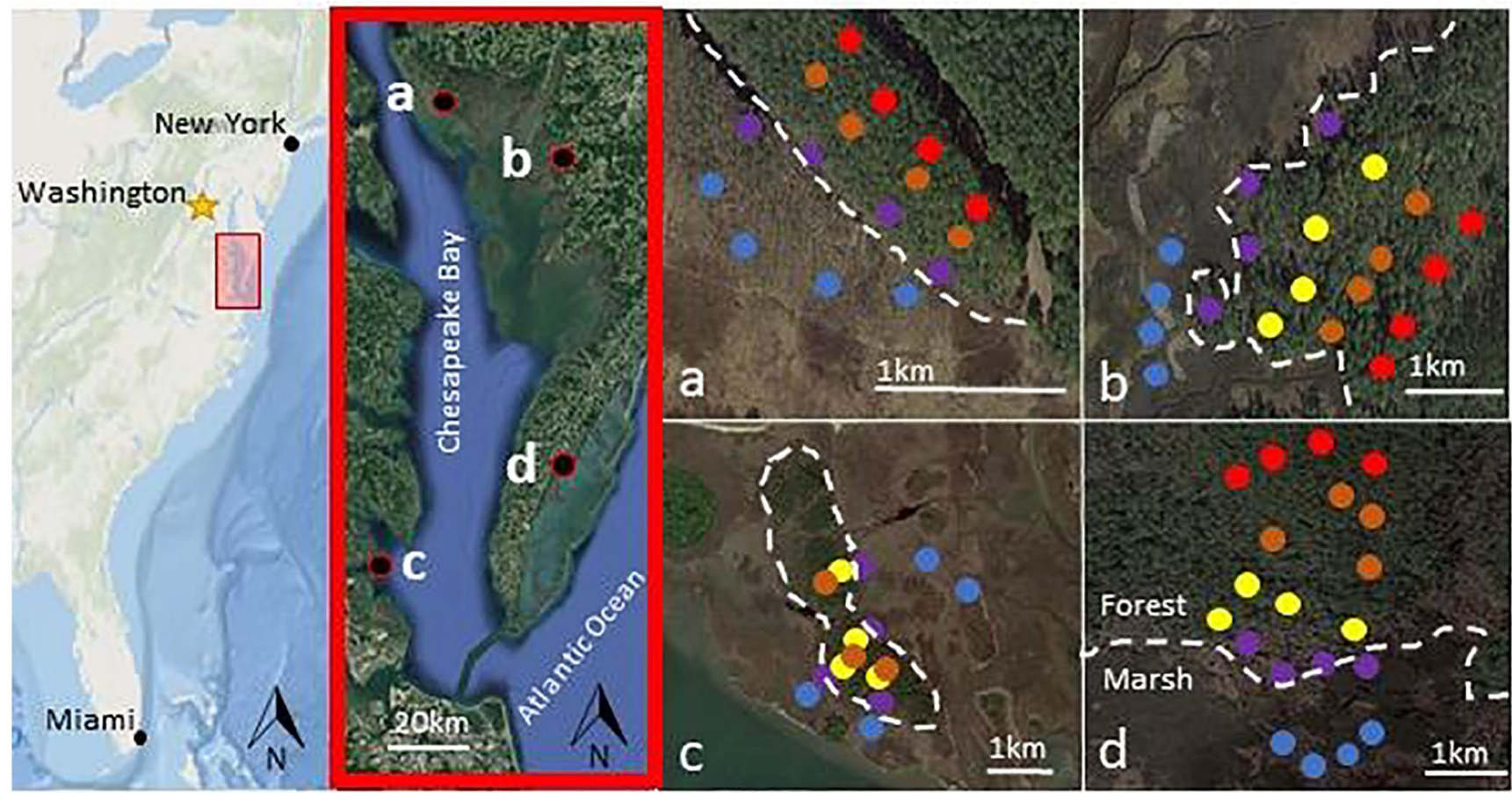

Figure 1. A general map of the Chesapeake Bay in Virginia and Maryland (U.S.) showing the region's location along the mid-Atlantic seaboard, site locations, and four inset maps showing individual sampling locations across the marsh forest boundary at each site (a) Moneystump Swamp, (b) Monie Bay, (c) Goodwin Island, (d) Phillips Creek. The vegetation zones are differentiated by symbol color. High marsh is blue, transition zone is purple, low forest is yellow, mid forest is orange, and high forest is red. The dashed line delineates the general marsh-forest boundary.

focusing on soil $\mathrm{C}$, this transgression should increase coastal $\mathrm{C}$ by replacing a low $\mathrm{C}$ burial system (upland forest) with a high C burial system (salt marsh) (Elsey-Quirk et al., 2011; Mcleod et al., 2011; Morris et al., 2016; Wang et al., 2019). Yet, this traditional approach largely ignores the contribution of $\mathrm{C}$ stored in biomass, which is known to be important in other systems. For example, living biomass accounts for $\sim 30 \%$ of $\mathrm{C}$ stored in mangroves and nearly half of $\mathrm{C}$ stored in the world's forests (Hamilton \& Friess, 2018; Pan et al., 2011). In contrast to terrestrial systems that exhibit positive carbon-climate feedbacks (Melillo et al., 2017), work in coastal wetlands points to a potentially negative carbon-climate feedback, where marsh soil carbon accumulation rates increase with warming-driven sea level rise (Doughty et al., 2016; Kirwan \& Mudd, 2012). However, we show here that tree biomass rather than soil organic matter dominates $\mathrm{C}$ stocks in rapidly migrating marsh-forest ecotones, so that sea level-driven marsh migration leads to a century scale loss of $\mathrm{C}$ that is, unaccounted for in our conceptual understanding of coastal $\mathrm{C}$ cycling.

\section{Methods}

\subsection{Approach and Study Area}

We measured biomass and soil $\mathrm{C}$ stocks across the forest-marsh ecotone at four rapidly transgressing sites in the Chesapeake Bay region of Maryland and Virginia in the United States of America (Figure 1). The Chesapeake Bay serves as a model region for studying the $\mathrm{C}$ implications of sea level-driven land conversion because rates of relative sea level rise (between 3 and $6 \mathrm{~mm} \mathrm{yr}^{-1}$ ) are twice as fast as eustatic rates $\left(\sim 2 \mathrm{~mm} \mathrm{yr}^{-1}\right)$ and the gently sloping, rural coast allows for many opportunities for marsh migration. Approximately 100,000 acres of salt marsh have migrated into retreating coastal forests since the mid-nineteenth century, and rates of forest retreat are accelerating in parallel with relative sea level rise (Schieder \& Kirwan, 2019; Schieder et al., 2018). Regional conditions in the Chesapeake Bay create rapid, widespread landscape changes that exemplify the slower, yet eventual, ecosystem shifts that salinization drives across the coastal landscape. 
Within the Chesapeake Bay, we studied sites at Goodwin Island (GI), Phillips Creek (PC), Monie Bay (MB), and Moneystump Swamp (MS). At each site, four transects starting in salt-unaffected forest and ending in young salt marsh that was once upland forest were established perpendicular to the marsh-forest ecotone. We identified and delineated five unique vegetation zones along the transects according to vegetation and forest health: high forest, mid forest, low forest, transition zone, and high marsh (Figure 1). The high forest is defined as a forest unaffected by salt intrusion displaying a mixed aged structure of both coniferous and hardwood trees. The mid forest displays early signs of salt stress and exhibits $100 \%$ hardwood tree mortality, but conifer seedling regeneration is present in the understory and the canopy has a predominantly healthy, mixed age structure. The low forest is defined by relatively higher salt stress, indicated by limited conifer regeneration, increased standing conifer tree mortality, and shrub species dominance in the understory. The transition zone has $\sim 50 \%$ mortality in all standing trees with an understory dominated by Phragmites australis and typical high marsh herbaceous species. The high marsh is dominated by herbaceous marsh grasses Distichlis spicata, Spartina alterniflora, and Spartina patens, and has no living canopy. This general vegetation pattern is observed in retreating coastal forests throughout the Atlantic Coast (Brinson et al., 1995; Kirwan \& Gedan, 2019; Langston et al., 2017; Smart et al., 2020; J. A. Smith, 2013; Williams et al., 2003), suggesting that our sites are broadly representative of the sea level-driven conversion of upland forest to marsh throughout the Atlantic Coast. As discussed below, simple projections of topography and sea level rise suggest that these spatial gradients in vegetation type correspond to the temporal evolution of the coastal landscape, where complete conversion of forest to marsh occurs in less than 100 years on average at our sites $\left(t_{\mathrm{mig}}\right.$, Table S1).

\subsection{Field Methods}

Within each vegetation zone along each transect, we established a $100-\mathrm{m}^{2}$ plot within which we surveyed vegetation and quantified $\mathrm{C}$ stocks. To estimate the total amount of $\mathrm{C}$ present within a plot, we estimated $\mathrm{C}$ within three distinct $\mathrm{C}$ stocks (woody $\mathrm{C}$, herbaceous $\mathrm{C}$, and soil $\mathrm{C}$ ). Woody $\mathrm{C}$ includes the above- (stem wood, bark, and branches) and belowground biomass of the trees and shrubs, and was estimated from allometric estimations of biomass. For trees, we used species-specific allometric equations to predict above and belowground biomass from diameter at breast height $(1.37 \mathrm{~m})$ measurements of all trees within the plot (Chojnacky et al., 2014; Clark \& Schroeder, 1985; Jenkins et al., 2003; Martin et al., 1998; McElligot \& Bragg, 2013; Norris et al., 2001; Ter-Mikaelian \& Korzukhin, 1997). Aboveground shrub biomass within the $100 \mathrm{~m}^{2}$ plot was approximated from allometric equations as a function of basal diameter and, belowground shrub biomass was approximated using a 1.098 root-to-shoot ratio for marsh shrubs (Conti et al., 2019; Mokany et al., 2006). Herbaceous $\mathrm{C}$ includes aboveground macrophyte biomass was destructively harvested from six randomly distributed $0.25 \mathrm{~m}^{2}$ plots nested within each $100 \mathrm{~m}^{2}$ plot during peak biomass (July-August 2019), separated into live and dead fractions, and dried to a constant weight.

Soil $\mathrm{C}$ was quantified by collecting three soil samples within each plot using a hand turn, four-inch soil mud auger in the forest zones and a Russian peat corer in the transition zone and high marsh. The soil $\mathrm{C}$ stock includes all organic $\mathrm{C}$ beneath unincorporated detritus and forest litter. To compare sediment samples from different vegetation zones with variable depths, soil samples were portioned into two depth intervals: 0-10 cm (hereafter referred to as "shallow soils"), which was consistent across vegetation zones, and $10 \mathrm{~cm}$ to parent material ("deep soils"), as defined by the point of resistance into inorganic clay or sand (Table S1). All soil samples were analyzed for dry bulk density (DBD) and percent organic matter using loss-on-ignition methods. To measure soil $\mathrm{C}$ accumulation rates, larger diameter $(15 \mathrm{~cm})$ cores were taken at two high marsh plots at each site for ${ }^{210} \mathrm{~Pb}$ gamma emission dating. Elevation relative to a benchmark at each site was measured at the center, highest, and lowest point of the plot using a laser level. The average value of each plot was then referenced to NAVD88, using an RTK GPS at the benchmark location, and mean higher high water (MHHW) using interpolated tide gauge data summarized in Holmquist et al. (2019). Statistical differences of similar stocks across the vegetation zones were calculated using a one-way ANOVA with a 95\% confidence interval applied to average stock values from the four sites. 


\subsection{Lab and Analytical Methods}

Biomass was converted to C using species-specific conversion ratios (McElligot \& Bragg, 2013; Norris et al., 2001) or using a general 50\% conversion for mixed herbaceous macrophytes, shrub, and deciduous tree biomass. Following the general approach of C. B. Craft et al. (1991), we converted the organic content of soils to total organic $\mathrm{C}$ (TOC) by constructing an empirical relationship for our sites and vegetation zones. Eight dried soil samples within each vegetation zone were selected to represent the range of organic matter from the vegetation zones. We then measured TOC by packaging $\sim 3 \mathrm{mg}$ of homogenized sediment in tin capsules, treating it with aerosolized $6 \mathrm{~mol} \mathrm{HCl}$ for $12 \mathrm{~h}$, drying the sample for an additional $12 \mathrm{~h}$, and processing the sample in a CHN analyzer (Thermo Electron Corporation FlashEA 1112, NC Soil Analyzer), which was calibrated using acetanilide standards $(71.09 \% \mathrm{C}, 10.36 \% \mathrm{~N})$. The relationship between organic matter and $\mathrm{C}$ was consistent across vegetation zones, so one collective relationship was used to estimate soil $\mathrm{C}$ content across all zones $\left(\mathrm{TOC}=0.0033(\% \mathrm{OM})^{2}+0.2967(\% \mathrm{OM})+8.4341, R^{2}=0.73\right)($ Figure $\mathrm{S} 1)$.

We measured soil salinity by preparing 1:5 soil to water suspensions from the top $10 \mathrm{~cm}$ of soil collected from three points in each plot (Hardie \& Doyle, 2012). The suspensions were homogenized according to Rhoades (1992), allowed to settle for $18 \mathrm{~h}$, and then filtered through a 20 micron filter to obtain extracts (He et al., 2012), which were measured using a FieldScout EC 450 Meter conductivity probe. To determine soil $\mathrm{C}$ accumulation rates in the high marsh sediment cores, we measured $\mathrm{Pb}^{210}$ activities down core using gamma spectrometry. We then applied the constant initial concentration (CIC) model, which approximates an average sediment accumulation rate, on dated sediment cores from the high marsh, with $\mathrm{Cs}^{137}$ as an independent chronometer (Appleby \& Oldfield, 1978; Sanchez-Cabeza \& Ruiz-Fernandez, 2012) (Figure S2). $\mathrm{C}$ accumulation rates were obtained by measuring $\mathrm{DBD}$ and the concentration of $\mathrm{C}$ in dated sediments and multiplying them by the accumulation rates derived from the CIC model (Arias-Ortiz et al., 2018).

\section{Results and Discussion}

\subsection{Shifting $\mathrm{C}$ Allocations in Marsh-Forest Ecotones}

The total $\mathrm{C}$ stock averaged across sites decreased by $\sim 50 \%$ from the high forest $\left(17.44 \pm 2.9 \mathrm{~kg} \mathrm{C} \mathrm{m}^{-2}\right)$ to the high marsh $\left(9.73 \pm 1.59 \mathrm{~kg} \mathrm{C} \mathrm{m}^{-2}\right)$. Total $\mathrm{C}$ was maximized in the mid forest $\left(22.1 \pm 0.63 \mathrm{~kg} \mathrm{C} \mathrm{m}^{-2}\right)$, though total $\mathrm{C}$ in the mid forest and high forest were not statistically different (Figure 2a, Figures S3-S6, $p=0.33$ ). Total C stocks increased with increasing elevation $\left(R^{2}=0.21, p=0.05\right)$ and decreasing salinity $\left(R^{2}=0.57\right.$, $p<<0.05$ ) (Figures 2e and 2f); both trends were consistent across all sites (Figure 2e). Based on a regionally averaged rate of sea level rise (SLR, $4.46 \mathrm{~mm} \mathrm{y}^{-1}$ ) and the difference in elevation between high forest and high marsh, we estimate that our chronosequence represents less than a century $\left(t_{m}=\Delta\right.$ Elevation/SLR), though this simple approach ignores pulse events and any dynamic feedbacks that could accelerate or mediate the transgression process (Figure 2e, Table S1).

The average $\mathrm{C}$ stock of living woody vegetation decreased from $13.2 \pm 4.0 \mathrm{~kg} \mathrm{C} \mathrm{m}^{-2}$ in the high forest to $0.18 \pm 0.02 \mathrm{~kg} \mathrm{C} \mathrm{m}^{-2}$ in the high marsh. Specifically, tree carbon decreased from $12.7 \mathrm{~kg} \mathrm{C} \mathrm{m}^{-2}$ to $0.09 \mathrm{~kg} \mathrm{C} \mathrm{m}^{-2}$ and shrubs decreased from 0.62 to $0.09 \mathrm{~kg} \mathrm{C} \mathrm{m}^{-2}$. Shrub density was maximized in the mid forest $\left(6.22 \mathrm{~kg} \mathrm{C} \mathrm{m}^{-2}, p<<0.05\right)$ where it accounted for $38 \%$ of $\mathrm{C}$ stored in woody biomass, but across every forest zone, $\mathrm{C}$ stored in trees was found to be greater than $\mathrm{C}$ stored in shrubs (Figure $2 \mathrm{~b}, p<<0.05$ ). Forest zones were consistently dominated by above ground, woody $\mathrm{C}$ in living biomass rather than herbaceous or soil $\mathrm{C}(p=0.06)$. Herbaceous $\mathrm{C}$ increased from the high forest $\left(0.03 \pm 0.01 \mathrm{~kg} \mathrm{C} \mathrm{m}^{-2}\right)$ to the high marsh $\left(0.34 \pm 0.03 \mathrm{~kg} \mathrm{C} \mathrm{m}^{-2}\right.$ ) (Figure $2 \mathrm{c}$ ). Herbaceous $\mathrm{C}$ was maximized in the transition zone at each site ( $p=0.08$ ) where Phragmites australis presence increased the herbaceous $\mathrm{C}$ stock by an average of $57 \%$ (Figure 2c, $p<<0.05$ ), compared to Moneystump Swamp where P. australis has historically been removed (Figures 2c and S4). The transition zone and high marsh had far smaller biomass $\mathrm{C}$ stocks, but had substantial contributions from soil C stocks. Deep soil C increased by an order of magnitude along the forest $\left(0.11 \mathrm{~kg} \mathrm{C} \mathrm{m}^{-2}\right)$ to marsh $\left(6.4 \mathrm{~kg} \mathrm{C} \mathrm{m}^{-2}\right)$ gradient while shallow soil $\mathrm{C}$ decreased slightly. Overall, soil $\mathrm{C}$ approximately doubled across the forest to marsh gradient and deep soil $\mathrm{C}$ contributed $70.3 \%$ of the total $\mathrm{C}$ stock in the high marsh (Figures 2d, 2a, and S5). Using the CIC model, the average vertical accretion rate across the high marsh zones of four sites was $2.35 \pm 0.84 \mathrm{~mm} \mathrm{y}^{-1}$ and ranged from 1.44 to $3.11 \mathrm{~mm} \mathrm{y}^{-1}$ (Figure S2, Table S1). Carbon accumulation rates calculated from dry bulk density, total organic carbon, and 

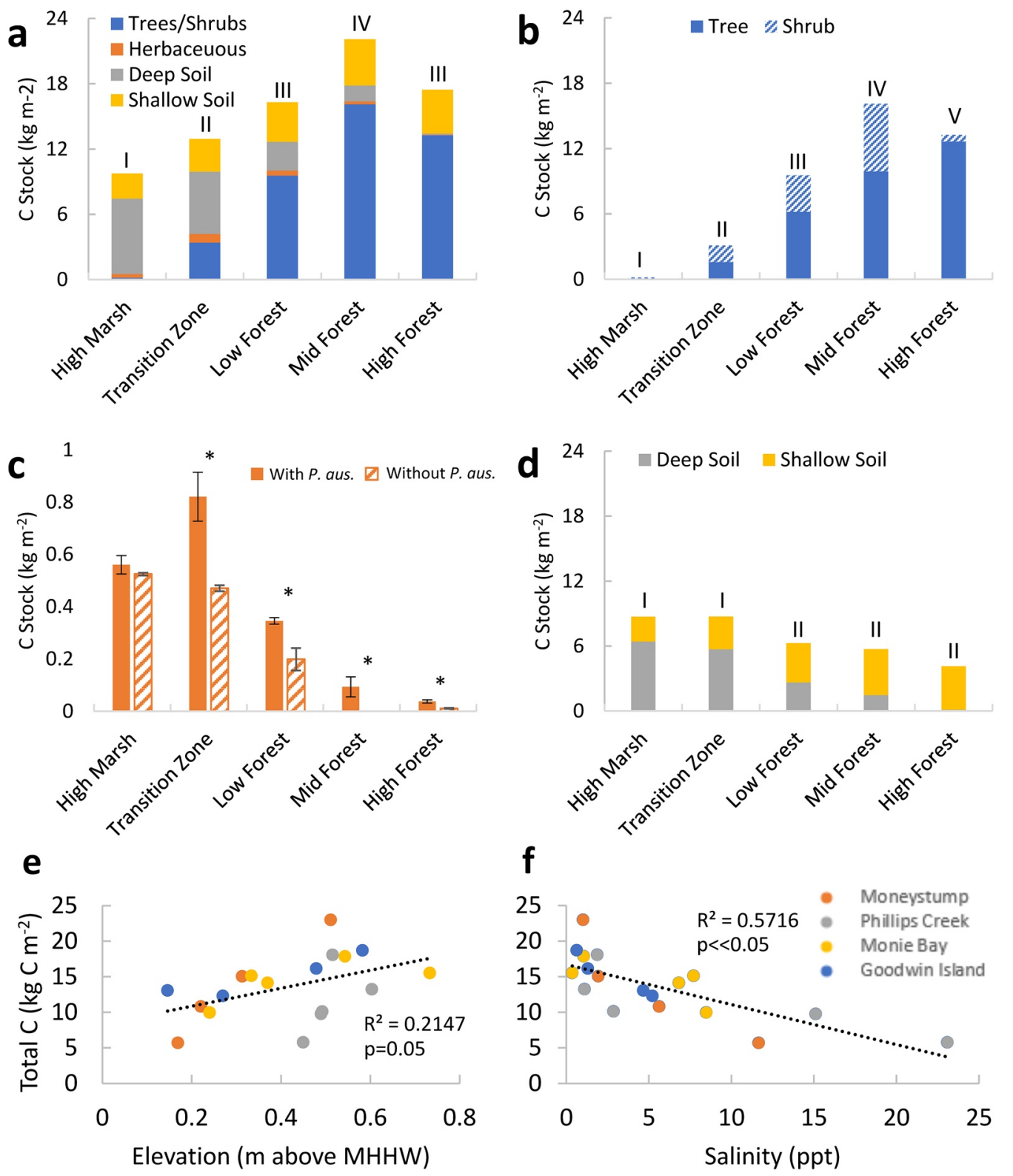

Figure 2. The $\mathrm{C}$ stock of distinct pools across the high forest to high marsh gradient, where the $\mathrm{C}$ stock refers to the average stock of four sites in the Chesapeake Bay. (a) Cumulative average $\mathrm{C}$ stocks by pool, (b) woody $\mathrm{C}$ partitioned into $\mathrm{C}$ stored in trees and shrubs, (c) herbaceous $\mathrm{C}$ separated into sites with and without $P$. australis, (d) soil $\mathrm{C}$ in upper $10 \mathrm{~cm}$ ("shallow") and from $10 \mathrm{~cm}$ to parent material depth ("deep"). Relationships between total C stock and elevation (e) and soil salinity (f) for each site and vegetation zone. The black dashed lines indicate the linear regression between total carbon stock and elevation (e, $y=12.63 x+8.323)$ and salinity (f, $y=-0.563 x+16.706)$. Roman numerals represent statistically significant differences between vegetation zones while asterisks $(*)$ represent statistically significant differences between sites with and without $P$. australis.

the CIC derived sedimentation rates varied between 0.036 and $0.065 \mathrm{~kg} \mathrm{C} \mathrm{m}^{-2} \mathrm{y}^{-1}$ (Table S1). Nevertheless, forest zones were consistently dominated by above ground biomass $\mathrm{C}$ rather than herbaceous or soil $\mathrm{C}$.

\subsection{Upland Transgression Decreases C Stocks}

For the last two decades, the paradigm in blue carbon research has maintained that vegetated intertidal systems disproportionately affect the global $\mathrm{C}$ cycle because rates of soil $\mathrm{C}$ burial far exceed those of terrestrial 
systems (Chmura et al., 2003; Duarte et al., 2005; Mcleod et al., 2011). By inference, sea level-driven conversion of terrestrial forests to tidal marshes would be expected to increase rates of $\mathrm{C}$ burial and consequently increase soil C stocks over time (Elsey-Quirk et al., 2011; Morris et al., 2012; Wang et al., 2019). Our finding that the magnitude of $\mathrm{C}$ stored in marsh soils is greater than coastal forest soils is consistent with this paradigm (Figure 2d). However, we also show that $\mathrm{C}$ stored within the living biomass of terrestrial, coastal forests far exceeds the total amount of $C$ stored in adjacent marshes (Figure 2a). This observation suggests that sea level-driven land conversion could lead to substantial losses of $\mathrm{C}$ that are not considered in current conceptual models of coastal C cycling.

The total $\mathrm{C}$ stock in forested zones was dominated by $\mathrm{C}$ stored in living trees, and tree mortality drove the decrease in total $\mathrm{C}$ across the forest-marsh ecotone (Figure 2a). We observed a strong, significant relationship between increasing soil salinity and decreasing total $\mathrm{C}$ (Figure $2 \mathrm{f}$ ), which is consistent with previous work that identifies salinity as a primary driver of tree mortality and forest retreat (Brinson et al., 1995; Williams et al., 2003). Our measures do not account for dead yet present vegetation, such as logs or standing dead trees, suggesting that we potentially overestimate the gradient in $\mathrm{C}$ stocks across the forest zones, and underestimate the gradient between stressed forest and high marsh. However, previous work suggests that living trees dominated the aboveground $C$ stock while dead woody vegetation comprised $<9 \%$ of aboveground C (K. Krauss et al., 2018). Additionally, far greater C stocks in live tree biomass than in marsh soils (Figures 2a, Smart et al., 2020) suggests that most carbon stored in live trees does not persist in marsh soils and is instead lost through decomposition, as indicated by rapid decomposition rates (Kozlowski, 1997) and elevated tree methane fluxes near the marsh-forest boundary (Martinez \& Ardon, 2021; Norwood et al., 2020). This indicates that forest carbon preservation is relatively small, but the exact quantification of preserved forest carbon is still unknown. The expansion of shrubs and $P$. australis and increasing soil organic matter thickness may increase $\mathrm{C}$ accumulation in migrating forest-marsh ecotones (C. Craft, 2000; Elsey-Quirk et al., 2011; McTigue et al., 2019; Smith, 2013) (Figure 2a). However, we find that these processes only partially offset tree mortality and that the net total C stock decreases by approximately $50 \%$ with the conversion of forest to marsh (Figure 2a).

Previous work in other transgressing coastal ecosystems suggests that sea level rise and saltwater intrusion may decrease total $\mathrm{C}$ stocks more generally. Ecosystem transgression in many regions of the U.S. is characterized by encroachment into wetland forests rather than the upland forests considered here (Brinson et al., 1995; Doyle et al., 2010). Wetland forests, despite having organic rich soils, experience decreased aboveground biomass associated with tree mortality where marshes replace forested wetlands (Brinson et al., 1995; K. Krauss et al., 2018; K. W. Krauss et al., 2007). In other systems, salinization and salt water intrusion into tidal freshwater systems has been shown to reduce $\mathrm{C}$ fixation (Herbert et al., 2018), increase soil respiration (Chambers et al., 2011), and lead to peat collapse (Chambers et al., 2014), resulting in decreased soil C stocks. Additionally, salt water intrusion reduces belowground biomass while also enhancing greenhouse gas efflux after prolonged exposure (Ardón et al., 2018; Wilson et al., 2018). These observations from mostly freshwater systems offer mechanistic insight into the processes that lead to decreases in specific carbon stocks and suggest that the patterns of loss we observe may apply more generally to other types of transgressing coastal systems (A. J. Smith \& Goetz, 2021).

\subsection{Timescales of C Replacement}

Although we find that marsh migration consistently leads to a net loss of total carbon (Figures 2a and S6), our finding that soil $\mathrm{C}$ stocks increase across the marsh-forest ecotone (Figure 2d) suggest that $\mathrm{C}$ stored in marshes may increase through time and perhaps eventually offset $\mathrm{C}$ lost from forest mortality. $\mathrm{C}$ stored in marsh soils increases through time as belowground organic matter accumulates in newly flooded, anaerobic soils (C. Craft et al., 1999; Stagg et al., 2016). Sediment cores taken from our study sites in much older sections of the marsh display deeper, organic rich soils reflecting larger carbon stocks typical of mature salt marshes (Dontis et al., 2020; Schieder \& Kirwan, 2019; Thomas, 2004). Carbon accumulation rates are also expected to increase with increasing tidal inundation associated with accelerated sea level rise (Gonneea et al., 2019; Kirwan \& Mudd, 2012; McTigue et al., 2019; Rogers et al., 2019). Thus, the size of the C stock in marshes and its ability to offset $\mathrm{C}$ loss due to forest mortality depends on marsh age. 


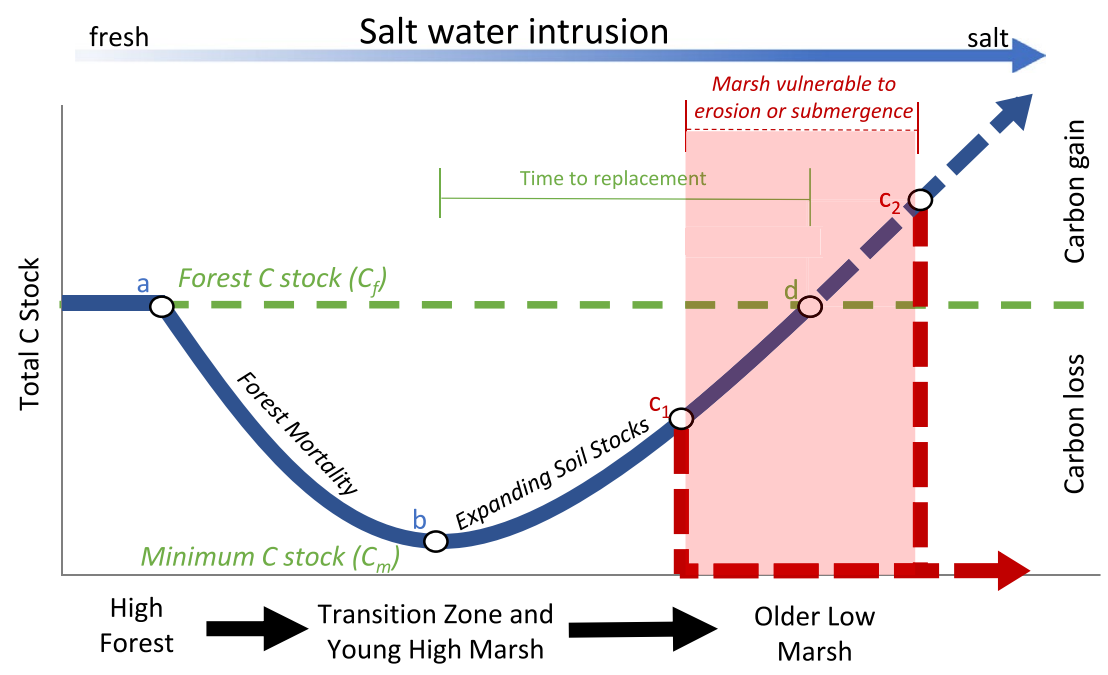

Figure 3. Conceptual diagram of the changing total $\mathrm{C}$ stock associated with the transition from forest to marsh. The total carbon stock in the forest $\left(C_{f}\right)$ decreases through time following salt water intrusion (a) in response to forest mortality. Carbon stocks reach a minimum $\left(C_{m}\right)$ when forests are first replaced by marshes (b), but then increase through time as developing marsh soils accumulate carbon. Carbon stocks increase with sea level rise until marshes submerge (c), potentially compensating for the loss of forest carbon (d). Variable times to submergence $\left(\mathrm{c}_{1}, \mathrm{c}_{2}\right)$ relative to the time to replacement (d) suggest that complete replacement of forest carbon is tenuous.

Given the high carbon accumulation rate in marsh soils and the high soil C content of older marshes (ElseyQuirk et al., 2011; Holmquist et al., 2018; K. Krauss et al., 2018), salt marshes may eventually offset C, that is, lost during marsh migration. We estimate the "time to replacement" of forest $\mathrm{C}$ at each site as:

$$
t_{r}=\frac{\Delta C_{f}}{\mathrm{CAR}_{m}}
$$

where $\Delta C_{f}$ is the total amount of $\mathrm{C}$ lost from the forest during transgression $\left(\mathrm{kg} \mathrm{m}^{-2}\right), C A R_{m}$ is the $\mathrm{C}$ accumulation rate in the adjacent high marsh $\left(\mathrm{kg} \mathrm{m}^{-2} \mathrm{y}^{-1}\right)$, and $t_{r}$ is the time (y) needed to replace the forest $\mathrm{C}$ lost with marsh soil $\mathrm{C}$. The inheritance of carbon from terrestrial systems into the migrating marsh soils is unknown and beyond the scope of this paper. To account for the unknown amount of inherited $\mathrm{C}$, we calculate $C_{f}$ in two ways. First, we assume that all $\mathrm{C}$ in the forest is lost during the transgression process so that $\Delta C_{f}=C_{f}$, where $C_{f}$ is the total forest $\mathrm{C}$ stock observed in the mid or high forest. This calculation represents the maximum time to replacement $\left(t_{r \text {,max }}\right)$ as it assumes no preservation of forest $\mathrm{C}$ in soils. Alternatively, we assume that a substantial fraction of $\mathrm{C}$ measured in the high marsh soils is $\mathrm{C}$ that has been preserved from forests, so that $\Delta C_{f}=C_{f}-C_{m}$, where $C_{m}$ is the measured marsh C stock, representing the minimum total $\mathrm{C}$ stock during marsh migration. This calculation represents a minimum time to replacement $\left(t_{r, \min }\right)$ as it includes refractory $\mathrm{C}$ in forest soils that has been preserved in soils during transgression, and assumes that any forest $\mathrm{C}$ in the high marsh soil will continue to be preserved in the future. Based on measured values of $C_{f}, C_{m}$, and $C A R_{m}$ at each of our sites, Equation 1 predicts that it will take $\sim 130-760$ years for marsh soil C to replace forest $\mathrm{C}$ lost during transgression (Table $\mathrm{S} 1$ ). This approach intentionally compares rates of $\mathrm{C}$ accumulation in one system with $\mathrm{C}$ stocks in another system, allowing us to calculate replacement timescales associated with migrating ecosystem boundaries in a manner that is easily applicable across ecosystems and spatial scales.

Our proposed replacement time metric leads to a conceptual model of changing carbon stocks that may be relevant to a variety of migrating ecosystems (Figure 3). In our system, the initial total C stock in the upland forests $\left(C_{f}\right)$ decreases with the onset of salt water intrusion (a). Progressive forest mortality leads to $\mathrm{C}$ loss until the total $\mathrm{C}$ stock is minimized $\left(C_{m}\right)$ when forests are first replaced by marshes (b), but developing marsh soils increase the total $\mathrm{C}$ stock through time and the system begins to partially offset lost $\mathrm{C}$. As the marsh ages, soil $\mathrm{C}$ stocks increase with sea level rise as developing marsh soils accumulate carbon until submergence (c), potentially compensating for or even exceeding the lost forest carbon (d). However, 
in the studied Chesapeake Bay region, marshes submerge or erode on timescales $\left(\mathrm{c}_{1}\right.$, $\mathrm{c}_{2}$; Hussein, 2009; Kirwan, Walters, et al., 2016; Schieder et al., 2018) that overlap with estimated times of carbon replacement (d, 130-760 years) (Table S1), suggesting that complete replacement of forest carbon is tenuous. Moreover, salt intrusion can lead to forest die-off without marsh migration (Taylor et al., 2020), leading to a large loss of aboveground $\mathrm{C}$ with little to no replacement in accumulating soil $\mathrm{C}$ stocks.

While the conceptual model is potentially generalizable across systems, the magnitude and rate of change would be expected to vary. For example, rapidly decreasing aboveground biomass and increasing belowground carbon stock is likely a common response to inundation and salinization, though rates would be determined by particular species tolerance and biogeochemical settings (Field et al., 2016; Flester \& Blum, 2020). In contrast to our reported long timescales of replacement, we expect $t_{r}$ to be relatively short in sequences beginning as freshwater wetlands or agricultural fields due to low values of $\Delta C_{f}$ from initial high soil C stocks or limited aboveground biomass, respectively (K. Krauss et al., 2018; Broek et al., 2016). Additionally, this framework can be applied to other transgressing systems, such as mangrove forest encroachment into hypersaline salt flats, to show that some transgressing ecosystems lead to rapidly increased carbon storage without having to replace lost C (Yando et al., 2016). The general framework we present is intentionally simplistic, thereby allowing for its application to larger scale landscape models parameterized with spatially variable terms or to other transgressing ecosystems with site specific information.

\subsection{Broader Implications}

The traditional focus on wetland soils leads to an important and unique negative carbon-climate feedback proposed for the coastal zone, where accelerated sea level rise drives faster soil C accumulation (Kirwan \& Mudd, 2012; Rogers et al., 2019; Wang et al., 2019). In contrast, our finding that C stored in the biomass of woody vegetation is far greater than the $\mathrm{C}$ stored in young, adjacent marshes (Figure 2) implies that sea level rise will lead to a net loss of $\mathrm{C}$ that cannot be predicted on the basis of wetland soil $\mathrm{C}$ stocks alone. Furthermore, our simple estimates of time to replacement suggest that the loss of $\mathrm{C}$ from forests following marsh migration will work against the proposed negative carbon-climate feedback in marsh soils at the scale of centuries (Table S1). Together, these findings help broaden the scope of traditional blue carbon research by connecting adjacent ecosystems, identifying a $\mathrm{C}$ source not considered in our current conceptual understanding of coastal carbon-climate feedbacks, and demonstrating that sea level rise will lead to fundamental changes in $\mathrm{C}$ allocation between soils and biomass at the coastal interface.

\section{Conflict of Interest}

Acknowledgments

K. Gedan, A. Langston, and D. Coleman provided direction for the design of this project. Sample collection and processing was done with the assistance of A. Chambers, T. Messerschmidt, J. Hu, J. Carr, D. Walters, Y. Feng, and J. Connell. The Chesapeake Bay National Estuarian Research Reserve System, The Nature Conservancy, and the Blackwater National Wildlife Refuge provided access to field sites. E. Theuerkauf and an anonymous reviewer provided beneficial comments to improve the manuscript. The Dominion Energy Charitable Foundation (Richmond Virginia), the U.S. National Science Foundation (LTER 1237733, CAREER 1654374), and the U.S. Department of Energy Terrestrial Ecosystem Science Program (DE-SC0021112, DESC0019110) funded this project. This is contribution no. 4025 of the Virginia Institute of Marine Science. Correspondence and material requests should be addressed to Alexander J Smith.
The authors declare no conflicts of interest relevant to this study.

\section{Data Availability Statement}

Elevation data was corrected using data available in this in-text data citation reference: Holmquist et al. (2019) and A. Smith et al. (2021). Carbon datasets generated from this project are publicly available in the Virginia Coastal Reserve Long Term Ecological Research Data Catalog (DOI: https://doi.org/10.6073/ pasta/4524c22708628eb7f06d174edae89ff2).

\section{References}

Appleby, P. G., \& Oldfield, F. (1978). The calculation of lead-210 dates assuming a constant rate of supply of unsupported $210 \mathrm{~Pb}$ to the sediment. Catena, 5, 1-8. https://doi.org/10.1016/s0341-8162(78)80002-2

Ardón, M., Helton, A. M., \& Bernhardt, E. S. (2018). Salinity effects on greenhouse gas emissions from wetland soils are contingent upon hydrologic setting: A microcosm experiment. Biogeochemistry, 140, 217-232. https://doi.org/10.1007/s10533-018-0486-2

Arias-Ortiz, A., Masqué, P., Garcia-Orellana, J., Serrano, O., Mazarrasa, I., Marbà, N., et al. (2018). Reviews and syntheses: 210 Pb-derived sediment and carbon accumulation rates in vegetated coastal ecosystems: Setting the record straight. Biogeosciences, 15, 6791-6818. https://doi.org/10.5194/bg-15-6791-2018

Brinson, M. M., Christian, R. R., \& Blum, L. K. (1995). Multiple states in the sea-level induced transition from terrestrial forest to estuary. Estuaries, 18, 648-659. https://doi.org/10.2307/1352383

Broek, M. V. D., Temmerman, S., Merckx, R., \& Govers, G. (2016). Controls on soil organic carbon stocks in tidal marshes along an estuarine salinity gradient. Biogeosciences, 13(24), 6611-6624. https://doi.org/10.5194/bg-13-6611-2016 
Chambers, L. G., Davis, S. E., Troxler, T., Boyer, J. N., Downey-Wall, A., \& Scinto, L. J. (2014). Biogeochemical effects of simulated sea level rise on carbon loss in an everglades mangrove peat soil. Hydrobiologia, 726, 195-211. https://doi.org/10.1007/s10750-013-1764-6

Chambers, L. G., Reddy, K. R., \& Osborne, T. Z. (2011). Short-term response of carbon cycling to salinity pulses in a freshwater wetland. Soil Science Society of America Journal, 75, 2000-2007. https://doi.org/10.2136/sssaj2011.0026

Chmura, G. L., Anisfeld, S. C., Cahoon, D. R., \& Lynch, J. C. (2003). Global carbon sequestration in tidal, saline wetland soils. Global Biogeochemical Cycles, 17(4), 1111. https://doi.org/10.1029/2002gb001917

Chojnacky, D. C., Heath, L. S., \& Jenkins, J. C. (2014). Updated generalized biomass equations for North American tree species. Forestry, 87, 129-151. https://doi.org/10.1093/forestry/cpt053

Clark, A. I., \& Schroeder, J. G. (1985). Weight, volume, and physical properties of major hardwood species in the southern Appalachian mountains (p. 63). Asheville, NC: US Department of Agriculture, Forest Service, Southeastern Forest Experiment Station.

Conti, G., Gorné, L. D., Zeballos, S. R., Lipoma, M. L., Gatica, G., Kowaljow, E., et al. (2019). Developing allometric models to predict the individual aboveground biomass of shrubs worldwide. Global Ecology and Biogeography, 28, 961-975. https://doi.org/10.1111/geb.12907

Craft, C. (2000). Co-development of wetland soils and benthic invertebrate communities following salt marsh creation. Wetlands Ecology and Management, 8, 197-207. https://doi.org/10.1023/a:1008448620605

Craft, C., Reader, J., Sacco, J. N., \& Broome, S. W. (1999). Twenty-five years of ecosystem development of constructed Spartina alterniflora (Loisel) marshes. Ecological Applications, 9, 1405-1419. https://doi.org/10.1890/1051-0761(1999)009[1405:tfyoed]2.0.co;2

Craft, C. B., Seneca, E. D., \& Broome, S. W. (1991). Loss on ignition and Kjeldahl digestion for estimating organic carbon and total nitrogen in estuarine marsh soils: Calibration with dry combustion. Estuaries, 14, 175-179. https://doi.org/10.2307/1351691

Dontis, E. E., Radabaugh, K. R., Chappel, A. R., Russo, C. E., \& Moyer, R. P. (2020). Carbon storage increases with site age as created salt marshes transition to mangrove forests in Tampa Bay, Florida (USA). Estuaries and Coasts, 43, 1470-1488. https://doi.org/10.1007/ s12237-020-00733-0

Doughty, C. L., Langley, J. A., Walker, W. S., Feller, I. C., Schaub, R., \& Chapman, S. K. (2016). Mangrove range expansion rapidly increases coastal wetland carbon storage. Estuaries and Coasts, 39, 385-396. https://doi.org/10.1007/s12237-015-9993-8

Doyle, T. W., Krauss, K. W., Conner, W. H., \& From, A. S. (2010). Predicting the retreat and migration of tidal forests along the northern Gulf of Mexico under sea-level rise. Forest Ecology and Management, 259, 770-777. https://doi.org/10.1016/j.foreco.2009.10.023

Duarte, C. M., Middelburg, J. J., \& Caraco, N. (2005). Major role of marine vegetation on the oceanic carbon cycle. Biogeosciences, $2,1-8$. https://doi.org/10.5194/bg-2-1-2005

Elsey-Quirk, T., Seliskar, D. M., Sommerfield, C. K., \& Gallagher, J. L. (2011). Salt marsh carbon pool distribution in a mid-Atlantic lagoon, USA: Sea level rise implications. Wetlands, 31, 87-99. https://doi.org/10.1007/s13157-010-0139-2

Enwright, N. M., Griffith, K. T., \& Osland, M. J. (2016). Barriers to and opportunities for landward migration of coastal wetlands with sea-level rise. Frontiers in Ecology and the Environment, 14, 307-316. https://doi.org/10.1002/fee.1282

Field, C. R., Gjerdrum, C., \& Elphick, C. S. (2016). Forest resistance to sea-level rise prevents landward migration of tidal marsh. Biological Conservation, 201, 363-369. https://doi.org/10.1016/j.biocon.2016.07.035

Flester, J. A., \& Blum, L. K. (2020). Rates of mainland marsh migration into uplands and seaward edge erosion are explained by geomorphic type of salt marsh in Virginia coastal lagoons. Wetlands, 40, 1-13. https://doi.org/10.1007/s13157-020-01390-6

Gonneea, M. E., Maio, C. V., Kroeger, K. D., Hawkes, A. D., Mora, J., Sullivan, R., et al. (2019). Salt marsh ecosystem restructuring enhances elevation resilience and carbon storage during accelerating relative sea-level rise. Estuarine. Coastal and Shelf Science, 217, 56-68. https://doi.org/10.1016/j.ecss.2018.11.003

Hamilton, S. E., \& Friess, D. A. (2018). Global carbon stocks and potential emissions due to mangrove deforestation from 2000 to 2012. Nature Climate Change, 8, 240-244. https://doi.org/10.1038/s41558-018-0090-4

Hardie, M., \& Doyle, R. (2012). Measuring soil salinity. Methods in Molecular Biology, 913, 415-425. https://doi. org/10.1007/978-1-61779-986-0_28

He, Y., DeSutter, T., Prunty, L., Hopkins, D., Jia, X., \& Wysocki, D. A. (2012). Evaluation of 1: 5 soil to water extract electrical conductivity methods. Geoderma, 185, 12-17. https://doi.org/10.1016/j.geoderma.2012.03.022

Herbert, E. R., Schubauer-Berigan, J., \& Craft, C. B. (2018). Differential effects of chronic and acute simulated seawater intrusion on tidal freshwater marsh carbon cycling. Biogeochemistry, 138, 137-154. https://doi.org/10.1007/s10533-018-0436-z

Holmquist, J. R., Windham-Myers, L., Bernal, B., Byrd, K. B., Crooks, S., Gonneea, M. E., et al. (2019). Coastal wetland elevation and carbon flux inventory with uncertainty, USA, 2006-2011. Oak Ridge, Tennessee, USA: ORNL DAAC. https://doi.org/10.3334/ORNLDAAC/1650

Holmquist, J. R., Windham-Myers, L., Bliss, N., Crooks, S., Morris, J. T., Megonigal, J. P., et al. (2018). Accuracy and precision of tidal wetland soil carbon mapping in the conterminous United States. Scientific Reports, 8, 9478. https://doi.org/10.1038/s41598-018-26948-7

Hopkinson, C. S., Cai, W. J., \& Hu, X. (2012). Carbon sequestration in wetland dominated coastal systems: A global sink of rapidly diminishing magnitude. Current Opinion in Environmental Sustainability, 4, 1-9. https://doi.org/10.1016/j.cosust.2012.03.005

Hussein, A. H. (2009). Modeling of sea-level rise and deforestation in submerging coastal utisols of Chesapeake Bay. Soil Science Society of America Journal, 73(1), 185-196. https://doi.org/10.2136/sssaj2006.0436

Jenkins, J. C., Chojnacky, D. C., Heath, L. S., \& Birdsey, R. A. (2003). National-scale biomass estimators for United States tree species. Forest Science, 49, 12-35.

Kirwan, M. L., \& Gedan, K. B. (2019). Sea-level driven land conversion and the formation of ghost forests. Nature Climate Change, 9 , 450-457. https://doi.org/10.1038/s41558-019-0488-7

Kirwan, M. L., \& Megonigal, J. P. (2013). Tidal wetland stability in the face of human impacts and sea-level rise. Nature, 504, 53-60. https:// doi.org/10.1038/nature12856

Kirwan, M. L., \& Mudd, S. M. (2012). Response of salt-marsh carbon accumulation to climate change. Nature, 489, 550-553. https://doi. org/10.1038/nature11440

Kirwan, M. L., Temmerman, S., Skeehan, E. E., Guntenspergen, G. R., \& Fagherazzi, S. (2016a). Overestimation of marsh vulnerability to sea level rise. Nature Climate Change, 6, 253-260. https://doi.org/10.1038/nclimate2909

Kirwan, M. L., Walters, D. C., Reay, W. G., \& Carr, J. A. (2016b). Sea level driven marsh expansion in a coupled model of marsh erosion and migration. Geophysical Research Letters, 43, 4366-4373. https://doi.org/10.1002/2016gl068507

Kozlowski, T. (1997). Responses of woody plants to flooding and salinity. Tree Physiology Monograph, 17, 13-21. https://doi.org/10.1093/ treephys/17.7.490

Krauss, K., Noe, G. B., Duberstein, J. A., Conner, W. H., Stagg, C. L., Cormier, N., et al. (2018). The role of the upper tidal estuary in wetland blue carbon storage and flux. Global Biogeochemical Cycles, 32, 817-839. https://doi.org/10.1029/2018gb005897 
Krauss, K. W., Chambers, J. L., \& Creech, D. (2007). Selection for salt tolerance in tidal freshwater swamp species: Advances using baldcypress as a model for restoration. Ecology of tidal freshwater forested wetlands of the southeastern United States (pp. 385-410). Dordrech: Springer.

Langston, A. K., Kaplan, D. A., \& Putz, F. E. (2017). A casualty of climate change? Loss of freshwater forest islands on Florida's Gulf Coast. Global Change Biology, 23(12), 5383-5397. https://doi.org/10.1111/gcb.13805

Martin, J. G., Kloeppel, B. D., Schaefer, T. L., Kimbler, D. L., \& McNulty, S. G. (1998). Aboveground biomass and nitrogen allocation of ten deciduous southern Appalachian tree species. Canadian Journal of Forest Research, 28(11), 1648-1659. https://doi.org/10.1139/x98-146

Martinez, M., \& Ardon, M. (2021). Drivers of greenhouse gas emissions from standing dead trees in ghost forests. Biogeochemistry, 154, 471-488. https://doi.org/10.1007/s10533-021-00797-5

McElligot, K. M., \& Bragg, D. C. (2013). Deriving biomass models for small-diameter loblolly pine on the Crossett Experimental Forest. Journal of the Arkansas Academy of Science, 67(1), 94-102.

Mcleod, E., Chmura, G., Bouillon, S., Salm, R., Björk, M., Duarte, C., et al. (2011). A blueprint for blue carbon: Toward an improved understanding of the role of vegetated coastal habitats in sequestering $\mathrm{CO}_{2}$. Frontiers in Ecology and the Environment, 7, 362-370.

McTigue, N., Davis, J., Rodriguez, A. B., McKee, B., Atencio, A., \& Currin, C. (2019). Sea level rise explains changing carbon accumulation rates in a salt marsh over the past two millennia. Journal of Geophysical Research: Biogeosciences, 124, 2945-2957. https://doi. org/10.1029/2019jg005207

Melillo, J. M., Frey, S. D., DeAngelis, K. M., Werner, W. J., Bernard, M. J., Bowles, F. P., et al. (2017). Long-term pattern and magnitude of soil carbon feedback to the climate system in a warming world. Science, 358, 101-105. https://doi.org/10.1126/science.aan2874

Mokany, K., Raison, R. J., \& Prokushkin, A. S. (2006). Critical analysis of root: Shoot ratios in terrestrial biomes. Global Change Biology, 12(1), 84-96. https://doi.org/10.1111/j.1365-2486.2005.001043.x

Morris, J. T., Barber, D. C., Callaway, J. C., Chambers, R., Hagen, S. C., Hopkinson, C. S., et al. (2016). Contributions of organic and inorganic matter to sediment volume and accretion in tidal wetlands at steady state. Earth's Future, 4, 110-121. https://doi. org/10.1002/2015ef000334

Morris, J. T., Edwards, J., Crooks, S., \& Reyes, E. (2012). Assessment of carbon sequestration potential in coastal wetlands, In R. Lal, K. Lorenz, R.R. Hüttl, B. Schneider, \& J. von Braun (Eds.). In Recarbonization of the biosphere: Ecosystems and the global carbon cycle (pp. 517-531). Springer. https://doi.org/10.1007/978-94-007-4159-1_24

Nahlik, A. M., \& Fennessy, M. S. (2016). Carbon storage in US wetlands. Nature Communications, 7, 1-9. https://doi.org/10.1038/ ncomms 13835

Norris, M. D., Blair, J. M., Johnson, L. C., \& McKane, R. B. (2001). Assessing changes in biomass, productivity, and C and N stores following Juniperus virginiana forest expansion into tallgrass prairie. Canadian Journal of Forest Research, 31(11), 1940-1946. https://doi. org/10.1139/x01-132

Norwood, M. J., Ward, N. D., McDowell, N. G., Myers-Pigg, A. N., Bond-Lamberty, B., Indivero, J., \& Megonigal, J. P. (2020). Coastal forest seawater exposure increases stem methane concentration. Journal of Geophysical Research: Biogeosciences, 126, e2020JG005915. https:// doi.org/10.1029/2020JG005915

Osland, M. J., Day, R. H., Hall, C. T., Brumfield, M. D., Dugas, J. L., \& Jones, W. R. (2017). Mangrove expansion and contraction at a poleward range limit: Climate extremes and land-ocean temperature gradients. Ecology, 98, 125-137. https://doi.org/10.1002/ecy.1625

Pan, Y., Birdsey, R. A., Fang, J., Houghton, R., Kauppi, P. E., Kurz, W. A., et al. (2011). A large and persistent carbon sink in the world's forests. Science, 333, 988-993. https://doi.org/10.1126/science.1201609

Rhoades, J. D. (1992). Instrumental field methods of salinity appraisal. Advances in measurement of soil physical properties: Bringing theory into practice, 30, 231-248.

Rogers, K., Kelleway, J. J., Saintilan, N., Megonigal, J. P., Adams, J. B., Holmquist, J. R., et al. (2019). Wetland carbon storage controlled by millennial-scale variation in relative sea-level rise. Nature, 567, 91-95. https://doi.org/10.1038/s41586-019-0951-7

Saintilan, N., Khan, N. S., Ashe, E., Kelleway, J. J., Rogers, K., Woodroffe, C. D., \& Horton, B. P. (2020). Thresholds of mangrove survival under rapid sea level rise. Science, 368, 1118-1121. https://doi.org/10.1126/science.aba2656

Sanchez-Cabeza, J. A., \& Ruiz-Fernandez, A. C. P. (2012). 210 sediment radiochronology: An integrated formulation and classification of dating models. Geochim. Cosmochim. Acta, 82, 183-200. https://doi.org/10.1016/j.gca.2010.12.024

Schieder, N. W., \& Kirwan, M. L. (2019). Sea-level driven acceleration in coastal forest retreat. Geology, 47, 1151-1155. https://doi. org/10.1130/g46607.1

Schieder, N. W., Walters, D. C., \& Kirwan, M. L. (2018). Massive upland to wetland conversion compensated for historical marsh loss in Chesapeake Bay, USA. Estuaries and Coasts, 41, 940-951. https://doi.org/10.1007/s12237-017-0336-9

Smart, L. S., Taillie, P. J., Poulter, B., Vukomanovic, J., Singh, K. K., Swenson, J. J., et al. (2020). Aboveground carbon loss associated with the spread of ghost forests as sea levels rise. Environmental Research Letters, 15(10), 104028. https://doi.org/10.1088/1748-9326/aba136

Smith, A., Kirwan, M., \& Messerschmidt, T. (2021). Carbon stocks in forests transitioning to salt marsh at four sites in the Chesapeake Bay region, 2019 ver 1. Environmental Data Initiative. https://doi.org/10.6073/pasta/4524c22708628eb7f06d174edae89ff2

Smith, A. J., \& Goetz, E. M. (2021). Climate changes drives increased directional movement of landscape ecotones. Landscape Ecology.

Smith, J. A. (2013). The role of phragmites australis in mediating inland salt marsh migration in a mid-Atlantic estuary. PLoS ONE, 8 , e65091. https://doi.org/10.1371/journal.pone.0065091

Stagg, C. L., Krauss, K. W., Cahoon, D. R., Cormier, N., Conner, W. H., \& Swarzenski, C. M. (2016). Processes contributing to resilience of coastal wetlands to sea-level rise. Ecosystems, 19, 1445-1459. https://doi.org/10.1007/s10021-016-0015-x

Taylor, L., Curson, D., Verutes, G. M., \& Wilsey, C. (2020). Mapping sea level rise impacts to identify climate change adaptation opportunities in the Chesapeake and Delaware Bays, USA. Wetlands Ecology and Management, 28, 527-541. https://doi.org/10.1007/ s11273-020-09729-w

Ter-Mikaelian, M. T., \& Korzukhin, M. D. (1997). Biomass equations for sixty-five North American tree species. Forest Ecology and Management, 97(1), 1-24. https://doi.org/10.1016/s0378-1127(97)00019-4

Theuerkauf, E. J., \& Rodriguez, A. B. (2017). Placing barrier-island transgression in a blue-carbon context. Earth's Future, 5, 789-810. https://doi.org/10.1002/2017ef000568

Thomas, C. R. (2004). Salt marsh biogeochemistry and sediment organic matter accumulation. University of Virginia. (Doctoral dissertation)

Wang, F., Lu, X., Sanders, C. J., \& Tang, J. (2019). Tidal wetland resilience to sea level rise increases their carbon sequestration capacity in United States. Nature Communications, 10, 1-11. https://doi.org/10.1038/s41467-019-13800-3

Ward, N. D., Megonigal, J. P., Bond-Lamberty, B., Bailey, V. L., Butman, D., Canuel, E. A., et al. (2020). Representing the function and sensitivity of coastal interfaces in Earth system models. Nature Communications, 11, 1-14. https://doi.org/10.1038/s41467-020-16236-2 
Williams, K., MacDonald, M., \& Sternberg, L. D. S. L. (2003). Interactions of storm, drought, and sea-level rise on coastal forest: A case study. Journal of Coastal Research, 19, 1116-1121.

Wilson, B. J., Servais, S., Mazzei, V., Kominoski, J. S., Hu, M., Davis, S. E., et al. (2018). Salinity pulses interact with seasonal dry-down to increase ecosystem carbon loss in marshes of the Florida Everglades. Ecological Applications, 28, 2092-2108. https://doi.org/10.1002/ eap. 1798

Yando, E. S., Osland, M. J., Willis, J. M., Day, R. H., Krauss, K. W., \& Hester, M. W. (2016). Salt marsh-mangrove ecotones: Using structural gradients to investigate the effects of woody plant encroachment on plant-soil interactions and ecosystem carbon pools. Journal of Ecology, 104(4), 1021-1031. https://doi.org/10.1111/1365-2745.12571 